\title{
MANUSKRIP MUSHAF AL-QUR'AN DAUN LONTAR KOLEKSI KIAI ABDURROCHIM (KAJIAN PEMAKAIAN RASM DAN QIRA'AT)
}

\author{
Qona'ah Dwi Hastuti, Moh. Abdul Kholiq Hasan \\ IAIN Surakarta \\ Jl. Pandawa, Pucangan, Kartasura, Sukoharjo, Jawa Tengah. \\ E-Mail: qonaahdwi563@gmail.com, hasanuniversitas@gmail.com
}

\begin{abstract}
Abstrak: Tulisan ini mengkaji manuskrip mushaf Al-Qur'an daun lontar koleksi Kiai Abdurrochim dari Tarub, Jawa Tengah. Hanya ada satu naskah yang menjadi obyek kajian. Fokus yang akan dibahas pada penelitian ini adalah bagaimana penggunaan rasm dan qira at pada naskah koleksi Kiai Abdurrochim tersebut. Hasil penelitian menemukan bahwa mushaf tersebut dalam penulisan rasm menggunakan kaidah rasm usmani, meskipun ada beberapa kesalahan dalam penulisan namun tidak mempengaruhi tulisan tersebut. Sedangkan pada aspek qira`at mushaf tersebut menggunakan qira`at Imam Ashim riwayat Hafs dalam menyalin teksnya. Meskipun ada beberapa kata dalam lafallafal tertentu yang masih merujuk pada qira 'at Qalun riwayat Nafi'.
\end{abstract}

Kata Kunci: Manuskrip Al-Qur'an daun lontar, Kiai Abdurrochim, rasm, qira`at.

Abstract: This research is analyzing the manuscript of Al-Qur'an on palm leaf collected by Kiai Abdurrochim from Tarub, Central Java. There is only one text being the object of the study. It is focused on how to use rasm and qira' at in the manuscript collected by Kiai Abdurrochim. The researchers found that the manuscript used usmani rasm rules in rasm writing, although there were some writing errors but they did not affect the writing. Whereas in the aspect of the qira'at of the manuscripts uses Imam Ashim's qira at based on the narration of Hafs in duplicating the text. Even though there are some words in certain pronunciations that still refer to Qalun's qira 'at based on the narration of Nafi'.

Keywords: Palm leaves manuscript of Al-Qur'an , Kiai Abdurrochim, rasm, qira'at

\section{PENDAHULUAN}

Penulisan Al-Qur'an sejatinya telah dilakukan sejak zaman Nabi Muhammad saw. (Suyuthi 1999: 87), ketika ayatayat Al-Qur'an turun, Rasulullah saw. memanggil beberapa sahabat untuk menuliskan ayat-ayat Al-Qur'an ke atas benda apa saja yang bisa ditulisi saat itu. Seperti pelepah kurma, potongan kayu, kepingan batu, sobekan kain, tulang, dan lembaran kulit binatang (Athailah 2010: 195) yang sudah disamak. ${ }^{1}$ Kemudian

1 Menyamak yaitu salah satu cara mensucikan benda dari najis, yaitu benda najis yang berupa kulit bangkai, baik kulit hewan bangkai hewan yang halal dagingnya ataupun tidak, kecuali kulit anjing dan babi serta pada zaman khalifah Usman bin Affan, Al-Qur'an mulai dikodifikasi menjadi satu mushaf yang kini di kenal dengan mushaf usmani. Sejak saat itu tradisi penulisan Al-Qur'an semakin meluas seiring dengan berkembangnya agama Islam yang menyebar ke berbagai Negara (Samsukadi: 23), hingga Islam menyentuh Nusantara. Penyebaran Islam di Nusantara berkembang demikian pesat, sehingga tidak sedikit ada beberapa pihak yang berkontribusi dalam penyalinan mushaf Al-Qur'an.

peranakannya. 
Penyalinan mushaf Al-Qur'an di Nusantara berlangsung dalam rentan waktu yang sangat lama yaitu sekitar 6500 tahun. Diperkirakan telah ada sejak sekitar akhir abad ke-13, ketika Samudra Pasai di ujung timur laut Sumatra menjadi kerajaan pesisir pertama di Nusantara yang memeluk Islam. Mushaf Nusantara tertua yang bisa diketahui sampai saat ini berada di Belanda yang menjadi koleksi William Marsden. Mushaf tersebut berasal dari Johor, Malaysia tahun 1606 (Akbar 2011: 10). Berpijak pada keterangan tersebut, tidak heran jika Indonesia sangat kaya dengan koleksi manuskrip mushaf kuno yang tersebar di sejumlah wilayah Nusantara, khususnya yang menjadi sentra penyebaran Islam pada masa lalu, seperti Aceh, Cirebon, Ternate, Bima, Yogyakarta, Surakarta, dan lain sebagainya (Mustopa 2015: 283).

Indonesia menjadi gudang naskah mushaf yang paling banyak, baik yang dimiliki oleh perorangan, museum, perpustakaan, masjid, maupun pesantren. Hal tersebut telah dibuktikan Puslitbang Lektur Keagamaan dengan inventarisasi dan penelitian mengenai mushaf di berbagai daerah pada tahun 2003 hingga 2005 (Syatri 2015: 326). Penyalinan mushaf Al-Qur'an bermula dari dorongan semangat dakwah dalam mengajarkan Al-Qur'an . Hal ini karena pada masa itu belum ada teknologi untuk penggandaan naskah, sehingga mengharuskan Al-Qur'an ditulis tangan. Tetapi pada penghujung abad ke-19 M minat penulisan mushaf Al-Qur'an di Indonesia semakin berkurang. Bahkan diperkirakan pembuatan seni mushaf AlQur'an mulai berhenti pada awal abad 20 (Akbar 2011: 68).

Ada tiga pihak yang memprakarsai penulisanmushafAl-Qur'an diNusantara, yaitu kerajaan, pesantren, dan elite sosial. Banyak mushaf yang ditulis oleh para seniman atas perintah sang raja di suatu tempat. Mushaf-mushaf kuno yang ada di bekas pusat-pusat kerajaan lama seperti mushaf Kiai Kanjeng Al-Qur'an yang berada di Kraton Yogyakarta, ditulis oleh seorang pegawai Kraton Surakarta, yaitu Ki Atma Parwita membuktikan hal tersebut (Hakim 2018). ${ }^{2}$ Adapun mushaf dari kalangan pesantren juga memegang peranan penting dalam penulisan mushaf Al-Qur'an . Sebagai contoh, mushaf yang ada di pesantren Tahfidzul Qur’an Kalibeber Wonosobo, mushaf dari Sumenep yang di tulis oleh Kiai Nur Ali Saronggi, dan lainnya (Hakim 2015: 153). Mushaf dari elit sosial seperti Mushaf Ibnu Sutowo dan terakhir mushaf at-Tin atas perintah Soeharto, mantan persiden RI (Musthofa 2013: 3).

Naskah-naskah tersebut masih bisa ditemui sampai saat ini, karena naskahnaskah tersebut tersimpan rapi baik di museum, pesantren, perpustakaan, maupun kolektor atau perorangan (Musthofa 2013: 3). Manuskrip Al-Qur'an daun lontar Abdurrochim yang dikaji ini adalah salah satu manuskrip mushaf AlQur'an yang dimiliki perorangan yaitu milik Kiai Abdurrochim yang berada di Dusun Tarub, Desa Tarub, Kecamatan Tawangharjo, Kabupaten Grobogan, Jawa Tengah. Penamaan manuskrip mushaf koleksi Abdurrochim adalah inisiatif penulis untuk memudahkan penyebutan manuskrip dalam penulisan ini.

Sejauh penelusuran penulis, manuskrip Al-Qur'an yang ditulis di atas daun lontar tersebut bukan satu-satunya manuskrip yang ada di Indonesia. Masih banyak lagi manuskrip-manuskrip daun lontar yang ada di wilayah-wilayah Indonesia. Seperti manuskrip Kiai Helmi dari Bogor (Latifah 2017: 4) yang mana

2 Abdul Hakim, "Kanjeng Kiai Al-Qur'an " Mushaf Pusaka Kraton Yogyakarta, artikel diakses pada 16 Oktober 2018 dari artikel Lajnah Pentashih Mushaf Al-Qur'an Badan Litbang dan Diklat Kementrian Agama Republik Indonesia, https://lpmq.inuxpro.com/artikel/223-kanjengkiai-al-qur-an-mushaf-pustaka-kraton-yogyakarta 
merupakan pemberian dari seorang yang tidak dikenal yang diyakini mengandung unsur mistis. Selain itu tulisan Ali Akbar dalam situs Kemenag mengatakan bahwa selain dalam bentuk buku (codek) ada AlQur'an "kuno-kunoan" dalam bentuk salinan diatas daun lontar. ${ }^{3} \mathrm{Hal}$ tersebut membuktikan bahwa perlunya penelitian terhadap mushaf daun lontar ini, apakah manuskrip mushaf daun lontar koleksi Kiai Abdurrochim ini juga merupakan AlQur'an "kuno-kunoan" atau benar-benar manuskrip yang sudah berumur tua?.

Manuskrip mushaf daun lontar koleksi Kiai Abdurrochim ini berada di kediaman Kiai Abdurrochim belum terlalu lama. Asal-usulnya pun masih kurang jelas. Uniknya manuskrip mushaf tersebut juga tidak mempunyai syakl atau tanda baca sebagaimana mushaf-mushaf lainnya. Tentu menimbulkan kecurigaan penulis, apakah memang disengaja tidak diberi tanda baca agar terkesan kuno. Sehingga diperlukannya kajian rasm dan qira`at pada mushaf tersebut. Karena pada abad ke 16-19 reseacrh membuktikan bahwa penulisan mushaf di Indonesia menggunakan rasm imla' $i^{4}$, yang mana pada aspek qira'at, rasm imla'i tidak mungkin bervariasi. (Muthoifin 2018: 3) Sehingga muncul ketertarikan atau kecurigaan penulis apakah mushaf daun lontar koleksi Kiai Abdurrochim ini menggunakan rasm usmani atau imla'i

3 Ali Akbar, Al-Qur'an “Kuno-kunoan”, LPMA, https://pmq.inuxpro.com/artikel/35-mushaf-alqur-an-kuno-kunoan, diakses pada tanggal 26 Juni 2019.

4 Rasm imla'i yaitu penulisan kata dalam AlQur'an yang sesuai dengan pelafalan atau bacaannya. Namun tidak berlaku untuk katakata yang sudah masyhur dan baku seperti kata

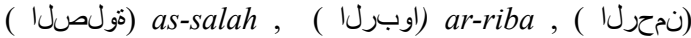
ar-rahman , maka penulisannya tetap sebagaimana tulisan yang masyhur. Hal ini bisa dilihat dalam tulisan Fakhrur Rozi "Dua Perbedaan Penulisan Rasm dalam Al-Qur'an cetak" yang diunggah oleh lajnah pentashihan mushaf Al-Qur'an , kementrian agama. https://lajnah.kemenag.go.id/artikel/386-duaperbedaan-penulisan-rasm-dalam-al-qur-an-cetak diakses pada pukul 00:24, minggu, 29 September 2019. dalam penulisannya, begitupun bacaan qira`at nya.

Penelitian ini adalah jenis penelitian kualitatif dengan pengolahan datanya menggunakan metode deskriptifanalisis dan bersifat studi kepustakaan (library reseacrh). Penelitian ini termasuk dalam model penelitian naskah kuno. Data primer dari penelitian ini adalah mushaf Al-Qur'an daun lontar koleksi Kiai Abdurrochim. Pendekatan filologi digunakan sebagai pisau analisis dalam penelitian ini.

\section{Deskripsi Naskah Koleksi Kiai Abdurrochim}

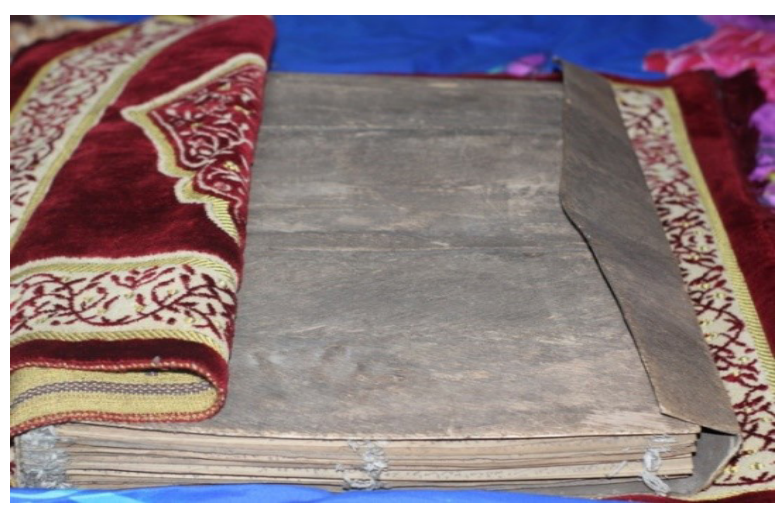

Gambar 1.

Mushaf ini adalah mushaf koleksi Kiai Abdurrochim seorang pemuka agama di Desa Tarub, Kabupaten Grobogan, Jawa Tengah. Mushaf tidak mempunyai kode mushaf karena mushaf tersebut termasuk mushaf yang dimiliki oleh perorangan. Nama pengarang naskah tidak disebutkan dalam naskah tersebut. Sekaligus nama penyalin tidak terdapat dalam naskah. Namun kepemilikan mushaf ini dimiliki Kiai Abdurrochim. Dari penelusuran penulis, Kiai Abdurrochim mengaku tidak mempunyai banyak informasi mengenai manuskrip. ${ }^{5}$ Mushaf ini adalah milik Kiai Thoyyib dari Jawa. Hal ini seperti yang di

5 Wawancara dilaksanakan pada pukul 15:50 WIB pada tanggal 08 November 2018 di kediaman Kiai Abdurrochim, Tarub. 
katakan bapak Ahmadi, selaku pemegang mushaf ke-5:

"yang membuat itu termasuke juga orang alim mbak Kiai Thoyyib bin Abdurrohman, asli keturunan Jawa dulunya pengasuh pondok. Usianya waktu menulis, ceritane sejak dulu ia belajar membaca Al-Qur'an dan menulis. ceritanya dulu orang mencari ilmu kemudian dapat istri anak kiai. Mushafnya ada banyak sekitar 9 mushaf, ada yang di Jawa, di Sumatra, dan ada yang dikasihkan, ada yang ditukar dengan ongkos mencari ilmu tadi. Saya mendapat mushaf yaitu awal pemerintahan Susilo Bambang Yudhoyono $(S B Y)^{\prime \prime}$

Artinya:"yang membuat mushaf itu termasuk orang alim, namanya Kiai Thoyyib bin Abdurrohman, asli keturunan Jawa yang juga pengasuh pondok. Usianya ketika menulis yaitu sejak ia belajar membaca dan menulis. ceritanya ia mencari ilmu disuatu pondok dan mendapat istri dari anak kiai tersebut. mushafnya banyak yaitu sekitar 9 mushaf, ada yang di Jawa, di Sumatra, dan ada yang diberikan, ada pula yang ditukar dengan uang sebagai ongkos mencari ilmu tadi. Saya mendapat mushaf yaitu pada awal pemerintahan Susilo Bambang Yudhoyono $(S B Y) . "{ }^{\prime \prime}$

Wawancara tersebut menginfokan bahwa mushaf tersebut tidak hanya satu yang beredar, akan tetapi terdapat 9 mushaf yang beredar, dan itu disengaja diproduksi dengan tujuan untuk diperdagangkan. Pak Kiai Ahmadi mendapat mushaf tersebut sejak masa pemerintahan SBY, yaitu sekitar 2004. Beliau juga menjelaskan bahwa pembuatan mushaf tersebut adalah pada awal pemerintahan Soeharto:

6 Wawancara dilaksanakan pada pukul 12:30 WIB tanggal 26 Februari 2019 di kediaman Kiai Ahmadi dari Demak, pemilik mushaf sebelum Kiai Abdurrochim, Tarub.
Artinya: "Saking mrika nipun pemerintahan Soeharto, yang membuat masih remajaremajanya masih kentheng, di pesantren, Pak yai Thoyyib dari Jawa timur ceritane niku dulu kala orang musafir ngudi bidang diagama di Jawa Timur. Jawa Timurnya mana yo mbk, aku kurang jelas, beliau sampun sedo, terus nek wong kali jowo penurunya saja ceritane nganu og mbak waktu masih pesantrennya sudah nggak ada ya penurunnya sekarang mungkin murid-murid seperti kita, seperti saya anggap seperti saya.

Artinya: "Dari sananya yaitu pada pemerintahan Soeharto, yang membuat kerika masih remaja, masih sehat-sehatnya, membuatnya di pesantren, pak kiai Thoyyib dari Jawa Timur, Jawa Timurnya mana ya mbak, aku kurang jelas, beliau sudah meninggal. Kemudian kata penurunnya yaitu waktu beliau masih ada pesantrennya sudah tidak ada penurunnya, sekarang bisa jadi penurunnya adalah murid-murid seperti kita, saya anggap seperti saya."

Pak Kiai Ahmadi hanya memberikan penjelasan, bahwa dari sananya (dari pemberi pertama) yaitu pada masa awal pemerintahan Soeharto. Beliau mengatakan bahwa penulisnya adalah Kiai Thoyyib dari Jawa Timur. Pak Kiai Thoyyib sudah meninggal, begitu pula tidak ada generasi yang melanjutkan perjuangannya.

Jadi pada aspek penanggalan, meskipun tidak ada informasi internal seperti penyebutan tertulis oleh penulisnya sendiri maupun oleh orang yang memiliki, akan tetapi bisa dipastikan melalui bukti eksternal yaitu wawancara dan uji sejarah dengan membandingkan teknik penulisan mushaf daun lontar koleksi Abdurrochim dan mushaf AlQur'an dari lajnah pentashih mushaf Al-Qur'an tahun 1960-an (yaitu pada zaman awal pemerintahan Soeharto). Maka diperkirakan usia mushaf tersebut 40 hingga 50 tahunan. 
Mushaf ini berukuran $50 \times 40 \times 6 \mathrm{~cm}$, ukuran panjang dan lebar pada halaman secara utuh memiliki panjang $50 \mathrm{~cm}$ dan lebar $40 \mathrm{~cm}$. Ukuran panjang dan lebar pada halaman yang digunakan untuk menulis yaitu berukuran panjang $50 \mathrm{~cm}$ lebar $37 \mathrm{~cm}$. Ukuran panjang dan lebar pada halaman yang tidak digunakan untuk menulis yaitu berukuran panjang $50 \mathrm{~cm}$ dan lebar $40 \mathrm{~cm}$. Ada 3 halaman yang tidak digunakan untuk menulis, yaitu 1 halaman kosong yang terdapat pada lembaran awal, dan 2 halaman kosong pada lembaran paling akhir. Lembaran tersebut $50 \mathrm{~cm}$ dan lebar $40 \mathrm{~cm}$.

Disalin dengan alas daun lontar yang pada satu halamannya terdiri dari 16 daun lontar, yang mana pada satu lontar terdiri dari 3 baris. Sehingga $3 \times 16=48$. Jadi dalam naskah mushaf Al-Qur'an daun lontar terdiri dari 48 baris pada setiap halaman. Pengecualian untuk surat al-Fātihah dan awal surat al-Baqarah, yang hanya terdiri dari 8 baris sekaligus nama suratnya. Nama surat ditulis ditepi bagian kanan, kecuali pada surat alFātihah dan al-Baqarah yang ditulis di tepi atas. Sampulnya terbuat dari pohon palem, mushaf ini tidak beriluminasi dan pada halaman awal menyisakan bagian kosong yang biasanya dihias. Ditulis menggunakan tinta hitam, dan berbahasa arab, karena dalam manuskrip adalah tulisan Al-Qur'an lengkap30juz. Terdapat dua kuras $^{7}$ pada setiap halaman, jika dijumlahkan maka jumlah keseluruhan 74 kuras. Penomoran menggunakan angka Arab, diletakkan pada setiap lembar bagian kiri dan tidak bolak balik, dimulai dari angka dua pada lembar daun ketiga, total jumlah keseluruhan halaman ada 39 halaman.

$7 \quad$ Kuras atau katern yang berarti susunan halamanhalaman buku atau majalah dalam selembar kertas besar. Setelah kertas besar dilipat, halaman-halaman akan tersusun sesuai nomor halamannya. Satu kuras biasanya terdiri dari 4,8 atau 16 halaman bolak balik (kelipatan 4). Untuk memudahkan penyebutan, kuras yaitu pengait antara lembar dalam melakukan penjilidan.
Kondisi naskah kurang baik, jilidnya sudah renggang dan terdapat tulisan yang memudar. Pada salah satu surat, yaitu suratal-anfal ditulis dua kali, hal ini sengaja dilakukan atau bisa jadi penulis mushaf lalai, sehingga mengalami beberapa corrupt pada mushaf. Kelalaian tersebut mungkin karena penulis mushaf tergesagesa dalam menuliskannya, mengingat dalam sebuah wawancara penulis pada pemilik mushaf bahwasanya mushaf tersebut sebenarnya ada 5 mushaf, dan salah satunya sudah diperjual-belikan.

Mushaf tidak ada kolofon sehingga tidak ada informasi internal mengenai penyalin dan tahun disalinnya naskah. Pada akhir halaman terdapat doa khotmil Qur'an yang terdapat pada penutup tulisan naskah.

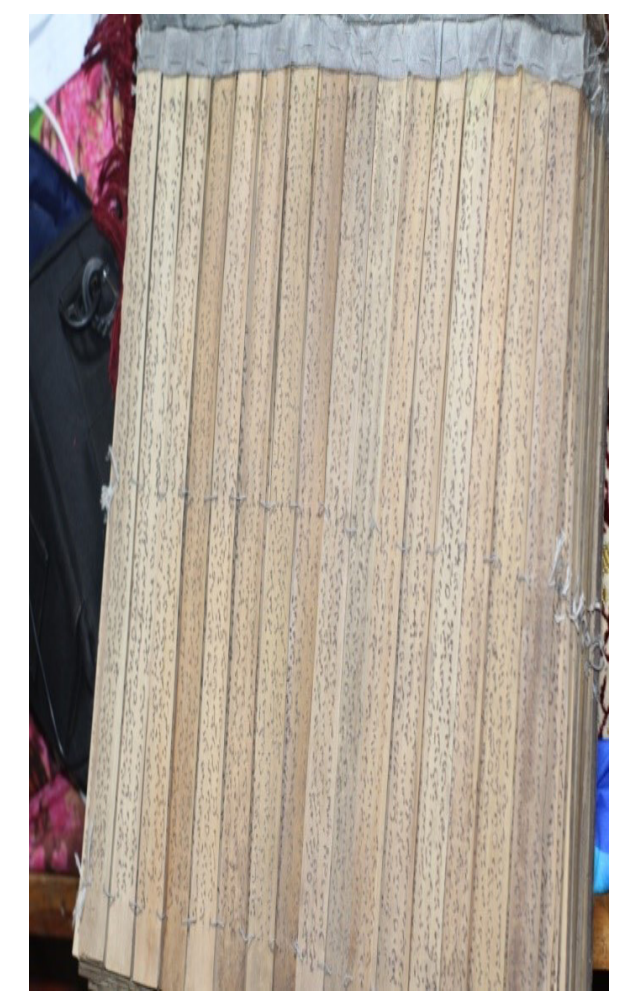

Gambar 2

\section{Telaah Penggunaan Rasm}

Kata rasm secara etimologi berasal dari kata rasama, yarsumu, rasma yang artinya menggambar atau melukis. Tercatat didalam kamus al-Munawwir bahwa rasm bisa diartikan sebagai sesuatu yang 
resmi atau menurut aturan (Munawwir 999: 1341). Menurut Zainal Arifin Madzkur definisi rasm secara etimologi dari beberapa literatur yang berarti رَثَآل bermakna bekas, peninggalan. Kata lain yang sama artinya dengan rasm adalah alkhāt, al-kitābah, as-zabū r, as-satrr, ar-raqm, arrasmu semuanya bermakna tulisan (Arifin 2012: 6). Secara sederhana, dari berbagai pengertian tersebut penulis mengartikan rasm adalah bentuk penulisan yang menganut aturan tertentu. (Fahrurozi 2018:2).

Secara terminologi terdapat beberapa interpretasi mengenai definisi rasm, diantaranya diartikan sebagai cara penulisan Al-Qur'an yang telah disetujui oleh Usman bin Affan pada waktu penulisan mushaf. ${ }^{8}$ Definisi tersebut selaras dengan Manna Khalil Qattan bahwa rasm usmani merupakan pola penulisan Al-Qur'an yang lebih menitik beratkan pada metode tertentu yang digunakan pada waktu kodifikasi mushaf pada zaman khalifah Usman bin Affan. Secara singkat menurut Islah ${ }^{9}$ menyebutkan bahwa rasm adalah teknik yang digunakan dalam penulisan ayat Al-Qur'an yang mana dalam penulisan tersebut terdapat beberapa model-model tertentu (Gusmian 2015: 45).

Beralih dari definisi dasar kata rasm, dalam diskursus Ulumul Qur'an, rasm dibahas lebih luas dalam ilmu rasm. Ilmu rasm ini muncul dari sejarah panjang mushaf usmani yang mengakomodir seluruh pola tulisan dalam Al-Qur'an . Secara teoritis ilmu rasm merupakan ilmu yang mempelajari tentang penulisan mushaf Al-Qur'an yang dilakukan

8 Bisa dilihat di buku Dapartemen Agama RI Badan Penelitian dan Pengembangan Agama Puslitbang Lektur Agama, Pedoman Umum dan Pentashihan Mushaf Al-Qur'an dengan Rasm Usmani, Jakarta: 1999, cet ke-1 h. 9.

9 Islah Gusmian adalah Dosen Tafsir Al-Qur'an di IAIN Surakarta, beliau mempopulerkan kajian-kajian lokalitas yang berbasis manuskrip keagamaan.Beliau juga menjabat sebagai ketua Pusat Kajian Naskah dan Khazanah Islam Nusantara di IAIN Surakarta. dengan cara khusus, baik dalam penulisan lafadz-lafadznya maupun bentuk-bentuk huruf yang digunakan. Seperti yang dikemukakan Badan Litbang, ilmu rasm usmani ini didefinisikan sebagai ilmu untuk mengetahui segi-segi perbedaan antara rasm usmani dan kaidah-kaidah rasm Qiyasi atau Imla'i $i^{10}$

Manuskrip Al-Qur'an yang berada di Nusantara kebanyakan menggunakan kaidah penulisan rasm imla'i dalam menulis teks Al-Qur'an . Sebagai contoh kajian yang dibuat oleh Asep Saifullah terhadap 29 manuskrip Al-Qur'an yang terdapat di Bayt Al-Qur'an dan Museum Istiqlal, Jakarta. ${ }^{11}$ Kajian tersebut menyebutkan seluruh manuskrip AlQur'an menggunakan rasm imla'i sebagai kaidah penulisan. Hal tersebut dapat dilihat pada kalimah-kalimah seperti menggunakan huruf alif dan tidak mengikuti kaidah rasm usmani. Namun, ada satu manuskrip Al-Qur'an dari Solo yang menggunakan rasm usmani sebagai kaidah penulisan (Saifullah 2008: 97).

Kaidah penulisan rasm usmani yang dipandang cukup populer adalah rumusan Suyuthi yang termaktub dalam al-Itqān fì `ulūm Al-Qur'an (Suyuthi, 1999: 167), namun yang menjadi rujukan utama yaitu rumusan Abu Amr Usman bin Said Ad-Dani dan Abu Dawud Sulaiman bin Najah, dua tokoh tersebut membidangi dalam ilmu ini (Arifin, 2018: 61). Untuk mengetahui kaidah yang digunakan dalam manuskrip mushaf Al-Qur'an daun lontar koleksi Kiai Abdurrochim ini, penulis akan membagi 13 sub-topik yang perlu dianalisis, yang merupakan bagian

10 Bisa dilihat diDapartemen Agama RI Badan Penelitian dan Pengembangan Agama Puslitbang Lektur Agama, Pedoman Umum dan Pentashihan Mushaf Al-Qur'an dengan Rasm Usmani, Jakarta: 1999, cet ke-1. H. 9

11 Diantaranya adalah manuskrip Al-Qur'an Lalino Bima, Al-Qur'an Batik Cirebon, Al-Qur'an Kauman Timur, Al-Qur'an Pandeglang dan manuskrip Al-Qur'an Cipete. Lihat di Riswadi h. 146. 
dari enam kaidah utama penulisan rasm usmani yang telah dirumuskan oleh Abu Amr Usman bin Said Ad-Dani dan Abu Dawud Sulaiman bin Najah sebagai berikut:
1. Hadfalif

Berikut tabel hadžf alif yang terdapat pada manuskrip mushaf AlQur'an daun lontar koleksi Kiai Abdurrochim:

Tabel 1. Penulisan hadžf alif

\begin{tabular}{|c|c|c|c|}
\hline No & $\begin{array}{c}\text { Keterangan } \\
\text { ayat }\end{array}$ & $\begin{array}{c}\text { Manuskrip Al-Qur'an } \\
\text { daun lontar koleksi } \\
\text { Kiai Abdurrochim }\end{array}$ & Rasm Usmani \\
\hline 1 & $1: 1$ & نosirus & بسم الله الرحمن الرحيم \\
\hline 2 & $1: 2$ & & العلمين \\
\hline 3 & $2: 2$ & S & ذلك \\
\hline 4 & $2: 21$ & Les & يايها الناس اعبدوا \\
\hline 5 & $2: 22$ & & 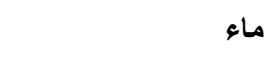 \\
\hline 6 & $2: 25$ & & هذا \\
\hline 7 & $2: 25$ & & الصلحت \\
\hline 8 & $2: 35$ & & 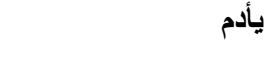 \\
\hline 9 & $2: 50$ & & فأنجينكم \\
\hline 10 & $2: 136$ & & و واسمعيل \\
\hline 11 & $2: 136$ & & 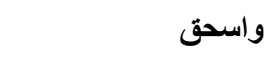 \\
\hline 12 & $2: 153$ & & الصبرين \\
\hline 13 & $2: 177$ & 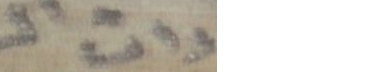 & واتى المال \\
\hline
\end{tabular}


PROFETIKA, Jurnal Studi Islam, Vol.21, No. 1, Juni 2020: 57-76

\begin{tabular}{|c|c|c|c|}
\hline No & $\begin{array}{c}\text { Keterangan } \\
\text { ayat }\end{array}$ & $\begin{array}{c}\text { Manuskrip Al-Qur'an } \\
\text { daun lontar koleksi } \\
\text { Kiai Abdurrochim }\end{array}$ & Rasm Usmani \\
\hline 14 & $2: 62$ & & الصبئين \\
\hline 15 & 2:196 & & ثلثة \\
\hline 16 & $2: 226$ & 93 & للاذين يؤلون \\
\hline 17 & $2: 226$ & $y^{7} x^{5} 1^{4}$ & فان فاعو \\
\hline
\end{tabular}

2. Hadf Waw

Berikut tabel hadžf waw yang

Al-Qur'an daun lontar koleksi Kiai terdapat pada manuskrip mushaf

Abdurrochim:

Tabel 2. Penulisan hadžf waw

\begin{tabular}{|c|c|c|c|}
\hline No & $\begin{array}{c}\text { Keterangan } \\
\text { ayat }\end{array}$ & $\begin{array}{c}\text { Manuskrip mushaf } \\
\text { Al-Qur`an daun lontar } \\
\text { koleksi Kiai Abdurrochim }\end{array}$ & Rasm Usmani \\
\hline 1 & 2: 14 & & مستهز عون \\
\hline 2 & $2: 31$ & & انبئوني \\
\hline 3 & $2: 251$ & & داود \\
\hline
\end{tabular}

3. hadžf $y a^{\prime}$

Berikut tabel hadžf ya' yang terdapat

Qur'an daun lontar koleksi Kiai pada manuskrip mushaf Al-

Abdurrochim:

Tabel 3. Penulisan hadžf $y a^{\prime}$

\begin{tabular}{lccc}
\hline No & $\begin{array}{c}\text { Keterngan } \\
\text { ayat }\end{array}$ & $\begin{array}{c}\text { Manuskrip mushaf } \\
\text { Al-Qur'an daun lontar } \\
\text { koleksi Kiai Abdurrochim }\end{array}$ & Rasm Usmani \\
\hline 1 & $2: 26$ & ي \\
2 & $2: 258$ & & \\
\hline
\end{tabular}




\section{2. hadžflam}

Berikut tabel hadžf lam yang terdapat pada manuskrip mushaf
Al-Qur'an daun lontar koleksi Kiai Abdurrochim:

Tabel 4. Penulisan hadžf lam

\begin{tabular}{|c|c|c|c|}
\hline No & $\begin{array}{c}\text { Keterangan } \\
\text { ayat }\end{array}$ & $\begin{array}{c}\text { Manuskrip mushaf } \\
\text { Al-Qur'an daun lontar kolek- } \\
\text { si Kiai Abdurrochim }\end{array}$ & Rasm Usmani \\
\hline 1 & $2: 22$ & $x^{3}, 38$ & الأى جعل لكم \\
\hline 2 & 2: 143 & & التي كنت \\
\hline 3 & 2: 164 & & اليل والنهار \\
\hline
\end{tabular}

\section{Ziyadah alif}

Berikut tabel terdapat pada manuskrip mushaf
Al-Qur‘an daun lontar koleksi Kiai Abdurrochim:

Tabel 5. Penulisan ziyadah alif

\begin{tabular}{|c|c|c|c|}
\hline No & $\begin{array}{c}\text { Keterangan } \\
\text { ayat }\end{array}$ & $\begin{array}{c}\text { Manuskrip mushaf } \\
\text { Al-Qur'an daun lontar kolek- } \\
\text { si Kiai Abdurrochim }\end{array}$ & Rasm Usmani \\
\hline 1 & 2: 24 & $\left(B^{3} x\right)^{4}, 4$ & فان لم تفعلوا ولن تفعلوا \\
\hline 2 & 2: 46 & $\because * 3: 25$ & ملقوا ربهم \\
\hline 3 & 2: 237 & & ولا تنسوا \\
\hline 4 & 2: 259 & $y^{a}$ & مائة عام \\
\hline 5 & 2: 275 & $(a)>1$ & الربوا \\
\hline 6 & 2: 275 & $-3 \times 2,5$ & الربوا \\
\hline
\end{tabular}


PROFETIKA, Jurnal Studi Islam, Vol.21, No. 1, Juni 2020: 57-76

\section{Ziyadah waw}

Berikut tabel ziyadah waw yang terdapat pada manuskrip mushaf
Al-Qur'an daun lontar koleksi Kiai Abdurrochim:

Tabel 6. Penulisan ziyadah waw

\begin{tabular}{|c|c|c|c|}
\hline No. & $\begin{array}{c}\text { Keterangan } \\
\text { ayat }\end{array}$ & $\begin{array}{c}\text { Manuskrip mushaf } \\
\text { Al-Qur'an daun lontar } \\
\text { koleksi Kiai Abdurrochim }\end{array}$ & $\begin{array}{l}\text { Rasm } \\
\text { Usmani }\end{array}$ \\
\hline 1 & $2: 3$ & Jiar? & ويقيمون الصلوة \\
\hline 2 & 2: 5 & & اولئك على \\
\hline 3 & 2: 43 & is & واتوا الزكوة \\
\hline 4 & 2: 96 & 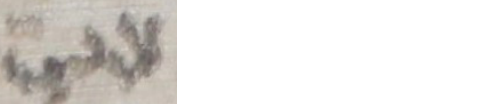 & على حيوة \\
\hline 5 & 2: 269 & 1 & أولوا الالبب \\
\hline
\end{tabular}

5. Ziyadah ya'

Berikut tabel terdapat pada manuskrip mushaf
Al-Qur'an daun lontar koleksi Kiai Abdurrochim:

Tabel 7. Penulisan ziyadah ya'

\begin{tabular}{|c|c|c|c|}
\hline No. & $\begin{array}{c}\text { Keterangan } \\
\text { ayat }\end{array}$ & $\begin{array}{c}\text { Manuskrip mushaf } \\
\text { Al-Qur'an daun lontar koleksi } \\
\text { Kiai Abdurrochim }\end{array}$ & $\begin{array}{l}\text { Rasm } \\
\text { Usmani }\end{array}$ \\
\hline 1 & 2: 269 & $\left.x_{2}+w^{4}+1\right)($ & يؤتى الحكمة \\
\hline 2 & $2: 276$ & is ind otys & ويربى الصدقت \\
\hline
\end{tabular}

\section{Penulisan hamzah}

Berikut penulisan hamzah yang terapat pada masuskrip mushaf Al-
Qur'an daun lontar koleksi Kiai Abdurrochim: 
Tabel 8. Penulisan hamzah

\begin{tabular}{|c|c|c|c|}
\hline No. & $\begin{array}{c}\text { Keterangan } \\
\text { ayat }\end{array}$ & $\begin{array}{c}\text { Manuskrip mushaf Al-Qur'an } \\
\text { daun lontar koleksi } \\
\text { Kiai Abdurrochm }\end{array}$ & Rasm Usmani \\
\hline 1 & 2:15 & & الله يستهزئ بهم \\
\hline 2 & $2: 27$ & 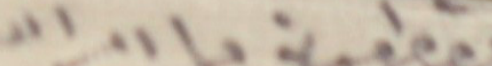 & ويقطعون مـا أمر الله \\
\hline 3 & 2: 108 & & سئل موسى \\
\hline
\end{tabular}

6. Badal alif kepada waw

Berikut adalah tabel badal alif kepada waw:

Tabel 9. Badal alif kepada waw

\begin{tabular}{|c|c|c|c|}
\hline No & $\begin{array}{c}\text { Keterangan } \\
\text { ayat }\end{array}$ & $\begin{array}{c}\text { Manuskrip Al-Qur`an } \\
\text { daun lontar koleksi } \\
\text { Kiai Abdurrochim }\end{array}$ & $\begin{array}{c}\text { Rasm } \\
\text { Usmani }\end{array}$ \\
\hline 1 & 2: 3 & $\dot{3 e n}_{3}$ & ويقيمون الصلوة \\
\hline 2 & 2: 96 & & على حيوة \\
\hline 3 & 2: 275 & & يأكلون الربوا \\
\hline
\end{tabular}

7. Badal alif kepada $y a^{\prime}$

Berikut tabel badal alif kepada ya' yang terdapat pada manuskrip mushaf
Al-Qur'an daun lontar koleksi Kiai Abdurrochim:

Tabel 10. Badal alif kepada $y a^{\prime}$

\begin{tabular}{|c|c|c|c|}
\hline No & Keterangan ayat & $\begin{array}{c}\text { Manuskrip mushaf } \\
\text { Al-Qur'an daun lontar koleksi } \\
\text { Kiai Abdurrochim }\end{array}$ & $\begin{array}{c}\text { Rasm } \\
\text { Usmani }\end{array}$ \\
\hline 1 & $2: 5$ & & على هدى \\
\hline 2 & $2: 28$ & 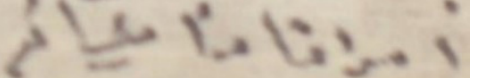 & أموتافاحيكم \\
\hline 3 & $2: 85$ & & أسرى \\
\hline 4 & 2: 194 & & فمن اعتدى \\
\hline
\end{tabular}


PROFETIKA, Jurnal Studi Islam, Vol.21, No. 1, Juni 2020: 57-76

8. Badalta'marbutahkepadaya'maftuhah manuskrip mushaf Al-Qur'an daun Berikut tabel Badal $t a^{\prime}$ marbuțah lontar koleksi Kiai Abdurrochim:

kepada ya' maftuhah yang terdapat pada

Tabel 11. Badal ta' marbuṭah kepada ya' maftuhah

\begin{tabular}{|c|c|c|c|}
\hline No. & $\begin{array}{c}\text { Keterangan } \\
\text { ayat }\end{array}$ & $\begin{array}{c}\text { Manuskrip mushaf } \\
\text { Al-Qur'an daun lontar } \\
\text { koleksi Kiai Abdurrochim }\end{array}$ & $\begin{array}{c}\text { Rasm } \\
\text { Usmani }\end{array}$ \\
\hline 1 & 2: 207 & thas & مرضات الله \\
\hline 2 & 2: 231 & & واذكروا نعمث الله \\
\hline
\end{tabular}

\section{Faṣl wa waṣl}

Berikut tabel kalimah faṣl wa wașl yang terdapat pada manuskrip mushaf
Al-Qur'an daun lontar koleksi Kiai Abdurrochim

Tabel 12. faṣl wa waṣl

\begin{tabular}{|c|c|c|c|}
\hline No. & $\begin{array}{c}\text { Keterangan } \\
\text { ayat }\end{array}$ & $\begin{array}{c}\text { Manuskrip mushaf } \\
\text { Al-Qur'an daun lontar } \\
\text { koleksi Kiai Abdurrochim }\end{array}$ & Rasm Usmani \\
\hline 1 & 2: 90 & 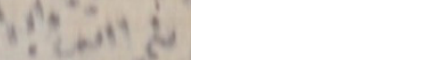 & بئسما اثتروا به \\
\hline 2 & 2: 93 & & قل بئسما \\
\hline 3 & 2: 114 & & ممن منع \\
\hline 4 & 2: 115 & & فائما \\
\hline 5 & 2: 144 & & وحيث ما كنتم \\
\hline 6 & 2: 164 & & من ماء \\
\hline 7 & 2: 240 & & في ما فعلن \\
\hline
\end{tabular}




\section{Rasm kalimat yang mempunyai dua bacaan atau lebih}

Tabel 13. Kalimat yang mempunyai dua bacaan atau lebih

\begin{tabular}{cccc}
\hline No. $\begin{array}{c}\text { Keterangan } \\
\text { ayat }\end{array}$ & $\begin{array}{c}\text { Manuskrip mushaf } \\
\text { Al-Qur'an daaun lontar } \\
\text { koleksi Kiai Abdurrochim }\end{array}$ & Rasm Usmani \\
\hline 1 & $1: 4$ & & \\
\hline
\end{tabular}

Berikutrasmkalimat yang mempunyai dua bacaan atau lebih pada manuskrip mushaf Al-Qur'an daun lontar koleksi Kiai Abdurrochim

Seperti yang sudah pengkaji paparkan melalui tabel diatas, dengan aspek rasm diantaranya hadžf alif, hadžf waw, hadžf ya', hadžf lam, ziyadah alif, ziyadah waw, ziyadah $y a^{\prime}$, penulisan hamzah, badal alif kepada waw, badal alif kepada ya', badal $t a^{\prime}$ marbuțah kepada ta' maftuhah, fașl dan wașl dan yang terakhir yaitu kalimah yang mempunyai dua bacaan atau lebih. Semua sub-topik tersebut merupakan pecahan dari enam kaidah utama yang telah ditetapkan oleh Abu Amr Usman bin Said ad-Dani (Ad-Dani, t.th: 170) dan Abu Dawud Sulaiman al-Najah (Al-Najah 2002: 215) dalam disiplin ilmu rasm.

Pembahasan pertama (hadžf alif) termasuk aspek hadžf yaitu salah satu dari enam ushul dalam kaidah rasm usmani. Untuk melihat apakah kaidah yang digunakan dalam penulisan manuskrip mushaf Al-Qur'an daun lontar koleksi Kiai Abdurrochim, pengkaji memberikan beberapa contoh seperti kalimat basmallah, penulis mushaf telah meng-hadžf-kan kata basmallah sebagaimana yang disepakati oleh Abu Amr Usman bin Sa'id al-Dani dan Abu Dawud Sulaiman al-Najah (Ad-Dani, t.th 220, Al-Najah 2002: 235) ${ }^{12}$. Pengkaji menemukan kalimat basmallah menggunakan kaidah yang sama pada mushaf Al-Qur'an daun lontar koleksi

12 Hal ini seperti yang dipaparkaan oleh Riswadi dalam tesisnya yang berjudul Analisis terhadap Manuskrip Al-Qur'an Terengganu IAMM 2012. 13.6 (lihat di Riswadi 216
Kiai Abdurrochim. Begitu juga pada

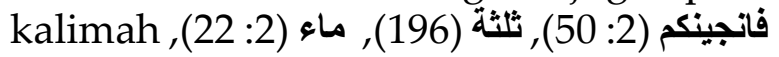

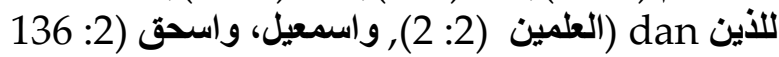
penulis mushaf telah meng hadžf kan alif, maka kalimat ini telah mengikuti kaidah penulisan rasm usmani.

Penulis dalam menuliskan mushaf daun lontar ini telah menghadfkan alif pada kalimah مدأي yang mengikuti pandangan Abu Amr ad-Dani dan Abu Dawud Sulaiman al-Najah. Hal ini juga berlaku pada ayat إياي سانلا (2: 21) pengkaji mendapati pada pada kalimah $y a^{\prime}$ seruan ini telah di-hadžf-kan alif pada seluruh surat al-Baqarah. Pada kaidah ini, penulis mushaf sudah menepati kaidah yang ditetapkan oleh kaidah penulisan rasm usmani.

Hal tersebut juga berlaku pada penulisan kalimat jama' mužakar salim العلمين (1: 2) الصبرين (2) 153 penulis telah meng-hadžf-kan alif, sama seperti pandangan keduanya, akan tetapi ada satu kalimat yang dalam penulisan ini penulis belum meng-ḥadžfkan alif-nya, yaitu الصبئين (2: 62 penulis الصابئين mushaf masih menuliskan dengan sehingga dalam penulisan ini penulis belum konsisten.

Selanjutnya kaidah ḩadžf alif pada kalimah yang didalamnya terdapat nama 'ajam, penulis juga meng-ḥadžf-kan sebagaimana kaidah rasm pada seluruh nama-nama 'ajam dalam Al-Qur'an seperti contoh 136 (2) (سمعيل (2: 136), اسحق '), Secara umum, penulis mushaf Al-Qur'an daun lontar koleksi Kiai Abdurrochim ini 
belum konsisten dalam penulisan kaidah hadžf alif.

Kedua hadžfwaw, Pengkaji mendapati penulis mushaf telah meng-hadžf-kan waw apabila terdapat dua waw dalam satu perkataan. Meskipun waw itu waw hamzah atau waw bagi jama' mužakar salim. Sebagai contoh pada kalimat مستهزءون (2:14) انبئونى 2:251 (25) ketiga kalimat ini asal penulisannya mempunyai dua waw, namun salah satu wawnya telah di-hadžfkan, pada kaidah ini, penulis mushaf sudah menepati kaidah yang ditetapkan dalam kaidah penulisan rasm usmani.

Ketiga hadžfya', pengkaji menemukan bahwa penulis mushaf telah meng-ḥadžfkan ya' pada dua kalimat yaitu يحتسي (2:26) dan (2:258) . hal ini sudah sesuai dengan kaidah penulisan rasm usmani.

hadžflam, apabila huruf lam didahului dengan alif lam al-ta'rif pada kalimat yang menunjukkan nama. Penulis mushaf telah

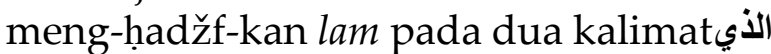

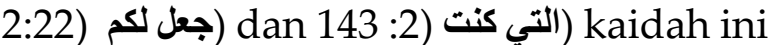
menepati apa yang ditetapkan oleh AdDani dan Abi Dawud.

Pembahasan selanjutnyayaituziyadah. Ziyadah bermaksud menambahkan suatu huruf yang tidak berfungsi atau tidak dibaca ketika wasal atau waqaf pada suatu kalimat. Biasanya huruf yang ditambah itu diletakkan diatasnya tanda bulat kecil pada huruf alif, waw dan ya', pembahasan mengenai aspek ini dibagi menjadi tiga bagian yaitu ziyadah alif, ziyadah waw dan ziyadah ya'. Untuk meneliti apakah kaidah yang digunakan oleh penulis mushaf, pengkaji akan menganalisisnya berdasarkan contoh sampel yang telah dirinci pada tabel di atas.

Pada kaidah ziyadah alif, penulis mushaf menambah huruf alif pada setiap ولاتنسوالون ا فان dan pada kalima (2) (2: 237), ملقوا (2:46 (2) الم تفعوا ولن تفعلو (2: begitu juga pada kalimat penulis mushaf telah menambahkan huruf alif, dan juga pada kalimat 259 (2). Pائة عام (Pengkaji mendapati secara umum dari semua kalimat dalam kaidah ziyadah alif ini penulis mushaf menepati kaidah yang digunakan dalam penulisan kaidah rasm.

Ziyadah waw, pembahasan mengenai ziyadah waw penulis mushaf juga telah menambahkan huruf waw pada kalimat yang telah ditetapkan kaidah penulisan rasm usmani. Seperti contoh pada kalimat اولثك (2: 5) اولوالالبب (2: 269), ويقيمون الصلوة

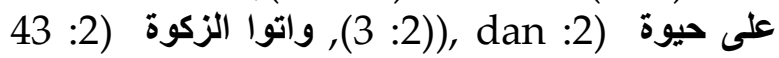
96) kaidah yang digunakan oleh penulis mushaf sudah memenuhi kaidah yang ditetapkan oleh Ad Dani dan Abu Dawud.

Penulisan hamzah, penulisan huruf hamzah terbagi menjadi dua, yaitu hamzah wasal dan hamzah qata'.13 Sebagai contoh dalam pembahasan penulisan hamzah wasal penulis mushaf tidak konsisten dalam meletkkan hamzah pada huruf alif,

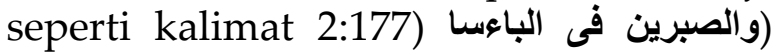

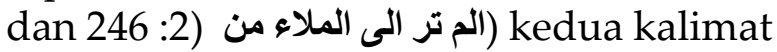
ini tidak diletakkan huruf hamzah. Sedangkan pada kalimat33: يأدم انبئه (2) penulis meletakkan huruf hamzah.

Begitupula pada pembahasan hamzah qata', penulis mushaf tidak konsisten

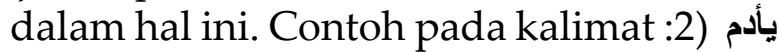
(اله يستهزء (2: (2), dan (33), سئل موسى (2: 108 beliau meletakkan huruf hamzah, akan tetapi pada kalimat 27 (امرالله به ويقطؤونما (2: beliau tidak meletakkan huruf hamzah pada huruf alif.

Secara umum punulis mushaf tidak konsisten dalam menulis penambahan hamzah. Karena penulis mushaf menulis huruf hamzah pada dua tempat hamzah

13 Hamzah wasal adalah huruf tambahan di awal kalimat yang hanya dibaca ketika dipermulaan bacaan dan digugurkan bacaannya jika disambung dengan kalimat sebelumnya. Ditandai dengan tanda (sad) diatasnya. Sedangkan hamzah qata' adalah huruf hamzah yang selalu dibaca berbaris atas, depan atau bawah titik, tidak gugur sebutannya baik diawal permulaan kalimat atau di tengah kalimat. Dan tidak gugur bacaannya walaupun berada diantara dua kalimat yang bersambung, ditulis di atas alif apabila berbaris atas atau depan, dan berbaris di bawah alif apabila berbaris di bawah, bentuknya seperti bentuk kepala 'ayn 
wașal dan satu tempat pada hamzah qata', sedangkan Ad-Dani dan Abu dawud sepakat menulis hamzah pada semua kalimat tersebut.

Pembahasan badal, dibagi menjadi tiga yaitu badal alif kepada waw, badal alif kepada ya' dan badal ta' marbutah kepada maftuhah. Mengenai badal alif kepada waw penulis mushaf telah mengikuti kaidah mem-badal-kan huruf alif kepada huruf ياكلون الريو (2): (2):

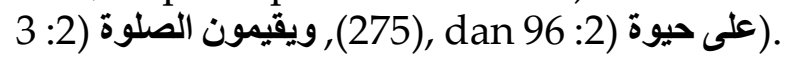
Penulis telah mengikuti kaidah yang telah ditetapkan oleh keduanya.

Badal alif kepada ya', terbagi menjadi dua, yaitu badal alif yang asal huruf alif itu adalah $y a^{\prime}$ dan alif yang asalnya dari $y a^{\prime}$ mushabbah. Seperti contoh dari isim فمن اعتدى dan dari fiil (على هاى (2: 5 yaitu $194: 2)$ ) kedua kata ini penulis mem-badalkan alif kepada ya', penulis mushaf dalam penulisan ini sudah mengikuti penulisan kaidah rasm usmani, begitu juga pada kata 85 :2 (اسرى yaitu huruf alif yang berasal berasal dari ya' mushabbah. Pada kalimat 28 (2) yaitu apabila huruf $y a^{\prime}$ ditulis dengan huruf alif karena pada asalnya terdapat dua huruf $y a^{\prime}$, penulis mushaf juga telah menepati kaidah dalam penulisan ilmu rasm.

Badal ta' marbutah kepada ta' maftuhah. Pada penulisan $t a^{\prime}$ marbutah kepada $t a^{\prime}$ maftuhah penulis juga sudah mengikuti penulisan yang benar sesuai dengan kaidah rasm usmani. Pengkaji mengambil

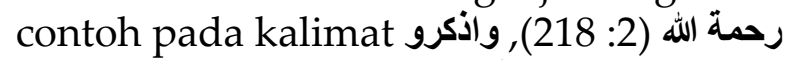

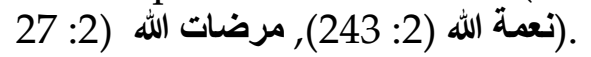

Fașl wa wașl merupakan antara kaidah kelima yang dibahas dalam kaidah rasm usmani yang berfungsi untuk memisah dan menyambungkan tulisan rasm pada huruf-huruf atau kalimat-kalimat tertentu. Dalam penulisan rasm usmani terdapat banyak kalimat yang ditulis dengan cara bersambung pada suatu tempat, namun ditulis dengan cara berpisah pada tempat yang lain dan sebaliknya. Seperti contoh, pada kalimat من منع dan من ماء (2): 164
114 :2)) yang tertulis terpisah dalam manuskrip mushaf Al-Qur'an daun lontar koleksi Kiai Abdurrochim, hal itu pun sudah sesuai dengan pandangan adDani dan Abu Dawud.

Rasm kalimat yang mempunyai dua bacaan atau lebih kaidah yang ke-enam adalah berkaitan dengan berbagai qira`at yang terdapat dalam satu kalimat. Seperti contoh pada kalimat 4 :1) ملك (م) kedua ulama rasm menulisnya tanpa alif dan menambah alif kecil setelah huruf mim untuk melerai perbedaan qira'at .

Secara keseluruhan dapat disimpulan bahwa penulis manuskrip mushaf Al-Qur'an daun lontar koleksi Kiai Abdurrchim telah mengikuti kaidah penulisan sesuai kaidah penulisan rasm usmani yang telah ditetapkan oleh Abu Amr Usman bin Said ad-Dani dan Abu Dawud Sulaiman al-Najah. Akan tetapi penulis masih ada kalimat yang tidak mengikuti kaidah keduanya. Artinya penulis belum konsisten terhadap penulisan rasm.

\section{Telaah Penggunaan Qira'at}

Secara etimologi kata qira'at (قرأة) merupakan bentuk mashdar dari qara'a (قرأ) yang berarti membaca (Munawwir 200- : 1603). Sedangkan secara terminologi, qira'at dalam pandangan ulama memiliki beberapa pengertian. Menurutal-Zarkashi qira'at adalah perbedaan lafal-lafal AlQur'an , baik mengenai huruf-hurufnya maupun tentang cara pengucapan huruf tersebut. Definisi lain dikemukakan oleh Dimyati yang juga diamini oleh alQastalani bahwa qira'at adalah ilmu untuk mengetahui cara pengucapan lafal Al-Qur'an baik yang disepakati maupun diperdebatkan oleh para ahli qira'at yang diperoleh dengan cara periwayatan (Hasanuddin 1995: 112).

Definisi diatas menyebutkan bahwasanya para ulama tersebut tidak hanya menganggap qira'at sebagai ragam pengucapan lafal, namun beliau juga 
menganggap qira'at sebagai disiplin ilmu, bahkan beliau juga menyebutkan bahwa sumber keberagaman qira'at disandarkan pada keterangan periwayatannya. Akan tetapi, ada pula ulama lain yang mendefinisikan qira`at dengan menisbahkannya kepada imam qira`at. Hal tersebut dikemukakan oleh Manna alQattan dalam rumusannya ${ }^{14}$ bahwa qira'at tidak hanya sebagai sebuah disiplin ilmu, namun juga telah berakumulasi dalam sebuah madzhab tertentu (Qattan t.t 184).

Hal senada juga disampaikan oleh Ali as-Sabuni dengan pendefisian bahwa qira'at adalah suatu mazhab tertentu dalam cara pengucapan Al-Qur'an , yang diikuti oleh salah seorang imam qira'at yang berbeda dengan mazhab lainnya serta berdasarkan pada sanad yang bersambung sampai Rasulullah saw. (Izzan 2011, 202)

Melihat beragamnya definisi qira 'at tersebut, maka disimpulkan bahwa makna qira at meliputi pertama, qira'at merupakan disiplin ilmu yang berdiri sendiri dan tersusun secara sistematis dan mempunyai metode tertentu, kedua, qira'at Al-Qur'an selalu disandarkan atau dinisbatkan kepada imam qira'at, bacaan tersebut bukan didasarkan atas hasil ijtihad, tetapi berlandaskan kepada riwayat yang sanadnya bersambung sampai kepada Rasulullah saw., ketiga qira`at adalah tata cara pengucapan lafadz-lafadz Al-Qur'an yangmana pernah diucapkan oleh Nabi Muhammad saw., atau oleh sahabat dihadapan beliau yang disetujuinya, sehingga qira'at tidak hanya terdiri satu bacaan, akan tetapi terdiri dari beberapa versi bacaan.

Beberapa mushaf kuno yang pernah ditemukan, ditulis dalam qira at riwayat Qalun dari Nafi' (Mustopa 2015: 179) dan ad-Duri dari Abu Amr (Akbar 2011) selain tertulis pada batang ayat, qira'at pada mushaf kuno juga kerap ditulis pada

14 Qira'at adalah sebuah mazhab dari beberapa mazhab artikulasi (kosa-kata) Al-Qur'an yang dipilih oleh salah seorang Imam Qira'at yang berbeda dengan mazhab lainnya. bagian pinggir mushaf, catatan pinggir tersebut menerangkan perbedaan qira'at dari satu kata menurut qira'at imam lain. Penulis akan memaparkan ayat yang dijadikan contoh analisis, berikut dengan perbandingan qira'at dari qira'at Ashim riwayat Hafs, dan qira'at Nafi' riwayat Qalun $^{15}$, hal ini untuk mengidentifikasi mazhab qira'at:

Surah Al-Fātihah ayat 3 (ملك) dibaca panjag huruf mimnya (مالك) nya bacaan ini merupakan qira'at riwayat Imam Ashim dan al-Kisa'i, sedangkan selain keduanya membaca dengan meng-ḥadžf-kan alif, seperti Imam Nafi', Abu Amr dan Ibnu Amir membacanya dengan pendek pada huruf mim (ملك), sedangkan dalam manuskrip mushaf daun lontar koleksi Kiai Abdurrochim ini bisa menggunakan qira`at Imam Nafi riwayat Qalun.

Pengkaji mendapati pada penulisan QS. Al-Fātihah ayat 6 tidak mengikuti qira'at Khallad yang membacanya dengan ishmam yaitu menyembunyikan huruf șad dengan huruf $z a$, tidak juga mengikuti qira'at Qunbul yang membacanya dengan sin. Tetapi mengikut pada Imam Hafs, Qalun dan Warsh yang membacanya dengan șad.

Al-Baqarah ayat 3 kata (يؤمنون) dibaca dengan menghadirkan hamzah sukun setelah huruf waw, bacaan ini merupakan qira'at riwayat Imam Qalun al-Madaniy, Imam Hafs, Imam Ibn Kasir al-Makiy, riwayat ad-Duri al-Bashri, Imam Ibn Amir As-Syami, Imam Ashim al-Kuffiy, Imam Hamzah al-Kuffy, Imam Ali alKisa'i. Sedangkan qira 'at riwayat Imam as-Susi dan Imam Wars dibaca dengan menghilangkan hamzah sukunnya menjadi (يومنون). Sedangkan dalam manuskrip mushaf Al-Qur'an daun lontar ini menggunakan qira`at Imam Ashim riwayat Hafs.

$15 \quad$ Hal ini seperti dalam jurnal suhuf tulisan Jonny Syatri dengan judul Telaah Qira'at dan Rasm pada Mushaf Al-Qur'an Kuno Bonjol dan Payamkumbuh yang menggunaan perbandingan antara bacaan Imam Ashim riwayat Hafs dan Imam Nafi' riwayat Qalun. 
Tabel 18. Perbedaan antara qira'at Qalun, qira`at Ashim, dan qira`at pada mushaf daun lontar koleksi Kiai Abdurrochim

\begin{tabular}{|c|c|c|c|c|c|}
\hline No. & Nama surat & Ayat & $\begin{array}{l}\text { Qira 'at Nafi' } \\
\text { riwayat Qalun }\end{array}$ & $\begin{array}{l}\text { Qira at Asim } \\
\text { riwayat } \\
\text { Hafs }\end{array}$ & $\begin{array}{l}\text { Mushaf Al-Qur'an } \\
\text { daun lontar koleksi } \\
\text { Kiai Abdurrochim }\end{array}$ \\
\hline 1 & Fatihah & 4 & 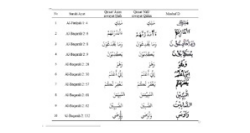 & 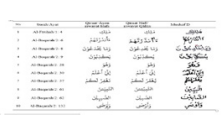 & $c^{5}=13$ \\
\hline 2 & Al-Fātihah & & الصرط & الصرط & \\
\hline 3 & Al-Baqarah & 3 & يؤمنون & يؤمنون & \\
\hline 4 & Al-Baqarah & 6 & 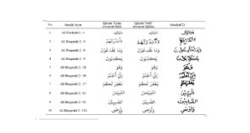 & 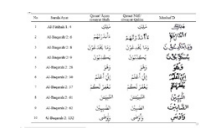 & $c^{4} x^{6} x^{3} y^{4}$ \\
\hline 5 & Al-Baqarah & 9 & 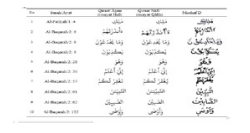 & وما يخدعون & 4 \\
\hline 6 & Al-Baqarah & 10 & 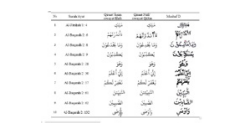 & يكذبون & 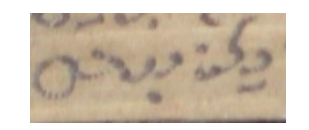 \\
\hline 7 & Al-Baqarah & 58 & 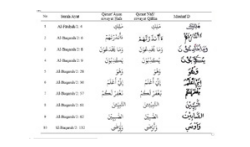 & 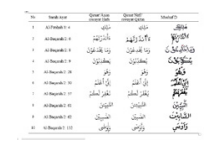 & 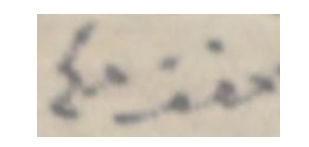 \\
\hline 8 & Al-Baqarah & 62 & 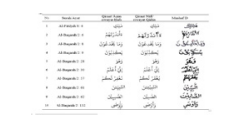 & 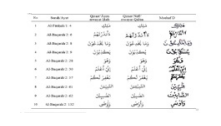 & \\
\hline 9 & Al-Baqarah & 116 & وقالوا اتخذ الله & وقالوا اتخذ الله & , 81,10, \\
\hline 10 & Al-Baqarah & 132 & 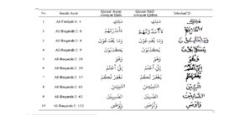 & ووصى & $3,35,0$ \\
\hline 11 & Al-Baqarah & 259 & ن ت نشر ها & تنشزها & \\
\hline
\end{tabular}

Surat Al-Baqarah (2: 6) أنذرتهم apabila dua huruf hamzah berbaris diatas pada setiap satunya Qalun, Abu Amr mentashil-kan yang keduanya yaitu antara hamzah dan juga alif, dan membaca Ibnu Kasir dan Warsh dengan tashil dan membaca pendek dan alif diantara keduanya
Pada surat al-Baqarah (2: 9) Imam Nafi', Abu Amr dan Ibnu Kasir membaca dengan alif sesudah huruf $k h a^{\prime}$, dan huruf dal dibaca kasrah, selainnya membaca dengan mati pada huruf $k h a^{\prime}$ dan huruf $d a l$ dibaca fathah oleh Imam Ashim, Hamzah dan al-Kisai dan Ibnu Kasir, pada manuskrip mushaf ini menggunakan 
qira`at Imam Ashim yaitu dibaca (وما (يخدعون)

Imam Nafi' dan Abu Amr dan Ibn Amir membaca pada QS: Al-Baqarah ayat 10 (نوبذانكي) dengan ya' dammah dan $k a f$ dibaca fathah sedangkan huruf dal di tasydid, selainnya membaca ya' di fathah, kaf dibaca sukun, dan dal di baca takhfif, mereka adalah Ashim, Hamzah, dan al-Kisai. Sedangkan pada manuskrip mushaf ini tidak ada syaklnya sehingga, bisa menggunakan keduanya.

Pada QS, Al-Baqarah ayat 58 (نغرلكم) Imam Nafi' membacanya dengan $y a^{\prime}$ dammah dan huruf $f a^{\prime}$ difathah. Ibnu Amir membacanya dengan $t a^{\prime}$ dammah serta baris atas pada $f a^{\prime}$ fathah juga. Selainnya membaca dengan (نغفركم) yaitu huruf nun fathah berbaris atas dengan fa' di kasrah. Pada manuskrip mushaf daun lontar ini pengkaji menyimpulkan menggunakan bacaan keduanya, karena pada huruf yang seharusnya nun atau $y a^{\prime}$, penulis mushaf tidak memberikan titik pada huruf tersebut, sehingga bisa dibaca nun

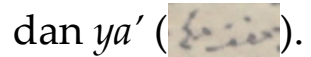

Imam Warsh membaca pada lafadz (الصبئين)al-Baqarah ayat 62, dengan imalah, dan Abu Amr dan Hamzah membaca dengan imalah, selain mereka membaca dengan fath. Pada mushaf daun lontar ini menggunakan bacaan Imam Ashim. Pada ayat (2: 166 (وقالوا اتخذ الله) Imam Ibn Amir membaca tanpa waw yaitu قالوا اتخذ اله sedangkan Imam yang lainnya seperti Imam Nafi', Imam Ashim, Ibnu Kasir dan lainnya membacanya dengan huruf waw. Dalam mushaf ini menggunakan waw sehingga jelas menggunakan bacaan Imam Ashim.

Pada surat al-Baqarah ayat 132 (ووصى) , Imam Nafi' dan Ibn Amir membaca kalimat tersebut dengan huruf alif depan waw yang pertama dan mematikan huruf waw yang kedua dan men-takhfif-kan huruf șad. Sedangkan selain mereka membaca dengan kedua-duahuruf waw dibaca fathah tanpa hamzah diantara kedua-duanya dan men-tasydid-kan huruf șad. Mushaf daun lontar ini menggunakan sebagaimana bacaan kedua. Yaitu membaca dengan kedua-dua huruf waw dibaca fathah tanpa hamzah diantara kedua-duanya dan mentashdid-kan huruf șad.

Pada kalimat (952:2) ننشزها) Imam Nafi', Ibnu Kasir dan Abu Amr membaca dengan huruf $r a^{\prime}$ (نتشرها) , sedangkan selain mereka membaca dengan huruf zai (ننشزها). Dalam penulisan lafadz tersebut, mushaf daun lontar ini mengikuti bacaan Imam selain Imam Nafi', Ibnu Kasir dan Abu Amr. Bisa jadi menggunakan bacaan Imam Ashim yaitu seperti penulisannya yang menggunakan huruf zai ( yaitu dibaca nunsyizuhā.

Berdasarkan pemaparan di atas, penggunaan qira`at pada mushaf daun lontar koleksi Kiai Andurrochim ini menggunakan riwayat bacaan Imam Ashim riwayat Hafs. Sebanyak sebelas contoh di atas yang menggunakan bacaan Imam Nafi' hanya satu yaitu pada surat al-Fatihah ayat 3 , sehingga penggunaan qira'at nya secara umum mengikiti riwayat Imam Ashim. Hal ini ternyata mempunyai persamaan dengan bacaan qira'at yang ada pada mushaf lajnah pentashih mushaf Al-Qur'an tahun 1969, dan tak menutup kemungkinan pula bahwa bisa jadi mushaf daun lontar koleksi Kiai Abdurrochim ini menyalin dari mushaf lajnah pentashih mushaf AlQur'an .

\section{SIMPULAN}

Mushaf Al-Qur'an daun lontar koleksi Kiai Abdurrochim pada aspek rasm telah menggunakan kaidah penulisan rasm usmani, yaitu seperti kaidah yang ditetapkan oleh Abu Amr Usman bin Said al-Dani dan Abu Dawud Sulaiman al-Najah terutama pada tujuh kaidah yang telah dibahas. Akan tetapi, terdapat beberapa kalimat yang menggunakan kaidah rasm imla' $i$, namun hal itu hanyalah 
sedikit dan tidak mempengaruhi qira`at Imam Ashim riwayat Hafs, yang keseluruhan naskah. Sedangkan aspek mana qira'at tersebut merupakan qira'at qira'at mushaf daun lontar ini mengikuti yang populer di masyarakat Indonesia.

\section{DAFTAR PUSTAKA}

An-Najah, Abu Dawud bin Sulaiman. 2002. Mukhtasyar at-Tabyiin li Hija'I at Tanzil. Riyad: Mamlakah al-Arabiyah as-Saudiyyah. Ditahkik oleh Ahmad bin Ahmad Muammar Syirsyal

Ad-Dani, Abu 'Amr Usman bin Sa'id. T.th. Al-Muqni' fi Rasm Masahif al-Amsar wa al-Ibtida' fi Kitab Allah 'Azza Wajalla. Beirut: Mussasah ar-Risalah

Al-Qur'an Mushaf Daun Lontar.

Al-Qur'an al-Karim. 1969. Lajnah Pentashih Mushaf Al-Qur'an . Jakarta: PT.

Unamga.

Al-Qur'an Terjemah Bi Rosm Utsmani Al-Qur'an Quddus. Tt. PT Buya Barokah

Ma'had Tahfid Yanbu'ul Quran Kudus.

Akbar, Ali. 2011. Mushaf Al-Qur'an di Indonesia dari Masa ke Masa. Badan Litbang dan Diklat Kementrian Agama RI.

. Al-Qur'an "Kuno-kunoan", LPMA, https://lpmq.inuxpro.com/ artikel/35-mushaf-al-qur-an-kuno-kunoan, diakses pada tanggal 26 Juni 2019.

Athaillah, H.A. 2010. Sejarah Al-Qur'an Verivikasi tentang Otentisitas Al-Qur'an . Yogyakarta: Pustaka Pelajar

Azmi, Riswadi. 2107. "Analisis Terhadap Manuskrip Al-Qur'an Terengganu IAMM 2012.13.6". Akademi Pengajian Al-Qur'an , Universiti Malaya, Kuala Lumpur.

Baried, Siti Baroroh (dkk). 1994. Pengantar Teori Filologi, Yogyakarta : Badan Penelitian dan Publikasi fakultas Seksi Filologi Sastra UGM.

Fahruozi dan Muthoifn, Nilai-Nilai Pendidikan Tauhid dalam Kisah Ashabul Ukhdud Surat Al-Buruj Perspektif Ibn Katsir dan Hamka, Jurnal Profetika, Jurnal Studi Islam, Vol. 19, No. 2, Desember 2018

Gusmian, Islah. 2012. Memahami Kalam Tuhan. Surakarta: IAIN Surakarta Press

Hakim, Abdul. 2015. “Khazanah Al-Qur'an Kuno Sumenep Sebuah Penelusuran Awal". Jurnal Agama dan Budaya Tsaqofah, Vol.13 No.02, Juli-Desember

T.th. "Kanjeng Kiai Al-Qur'an " Mushaf Pusaka Kraton Yogyakarta. Lajnah Pentashih Mushaf Al-Qur'an Badan Litbang dan Diklat Kementrian Agama Republik Indonesia, https://lpmq.inuxpro.com/artikel/223-kanjeng-kiai-al-qur-an-mushaf-pusakakraton-yogyakarta. diakses pada 16 Oktober 2018.

. 2018. “Metode Kajian Rasm, Qira`at, Wakaf dan Dabt pada Mushaf Kuno Sebuah Pengantar". Jurnal Suhuf, Vol. 11, N0. 1, Juni.

Hasanuddin AF. 1995. Anatomi Al-Qur'an Perbedaan Qira'at dan Pengaruhnya terhadap Istinbat Hukum dalam Al-Qur'an. Jakarta: Raja Grafindo Persada

Izzan, Ahmad. 2011. Ulumul Qur'an. Bandung: Tafakkur. 
Latifah, Lulu'atun. 2017. "Kekhasan Manuskrip Daun Lontar Milik Kiai Helmi. (Kajian Filologi dan Resepsi)". Skripsi Fakultas Ushuluddin dan Pemikiran Islam Universutas Islam Negri Sunan Kalijaga, Yogyakarta.

Madzkur, Zainal Arifin. 2012. "Mengenal Rasm Usmani: Sejarah, Kaidah dan Hukum Penulisan Al-Qur'an dengan Rasm Usmani", Lajnah Pentashih Mushaf AlQur'an . Jurnal Suhuf. Vol. 5, No. 1.

. 2018. Perbedaan Rasm Usmani(Antara Mushaf Standar Indonesia dan Mushaf Madinah Saudi Arabia dalam Prespektifad-Dani san Abu Dawud. Jakarta: Azza Media

Munawwir, Ahmad Warson. 1997. Munawwir Kamus Arab Indonesia. Surabaya: Pustaka Progresif

Mustopa. 2015. “Mushaf Kuno Lombok, Telaah Aspek Penulisan Dan Teks”. Jurnal Suhuf Vol. 10 No. 1 juni . 2013. “Keragaman Qira`at dalam Kesaksian Mushaf Kuno

Muthoifin, Mengungkap Isi Pendidikan Islam Perspektif Al-Qur'an Surat Al-Ashr Ayat 1-3, Proseding the 7th University Research Colloqium 2018 STIKES PKU Muhammadiyah Surakarta, 2018.

Nusantara". Suhuf Vol. 7, No. 22 November

Qattan, Manna Khalil. 2013. Studi Ilmu-Ilmu Al-Qur'an, cet 16. Bogor. Pustaka Litera AntarNusa.

Rozi, Fakhrur. T.th "Dua Perbedaan Penulisan Rasm dalam AlQur'an cetak" . Lajnah Pentashih Mushaf Al-Qur'an Badan Litbang dan Diklat Kementrian Agama Republik Indonesia, https://lajnah.kemenag.go.id/artikel/386-dua-perbedaan-penulisan-rasm-dalamal-qur-an-cetak, diakses pada 29 September 2019.

Saifullah, Asep. 2008. "Aspek Rasm Tanda Baca dan Kaligrafi pada Mushaf-Mushaf Kuno Koleksi Bayt Al-Qur‘an dan Museum Istiqlal Jakarta". Jurnal Suhuf, Vol. 1, No. 1.

Samsukadi, Muhammad. T.th. "sejarah Mushaf Ustmani (Melacak Transformasi AlQur 'an dari Teks Metafisik sampai Textus Receptus)". Jurnal Religi Studi Islam (Jombang: UPT Daarul ‘Ulum)

Suyuthi, Jalaluddin. 1999 al-Itqān fì 'Ulūm Al-Qur'an , Ed. Khalid al-Attar. Beirut: Dar al-Fikr.

Syatri , Jonni. 2015. “Telaah Qira`at dan Rasm pada Mushaf Al-Qur'an Kuno Bonjol dan Payamkumbuh". Jurnal Suhuf, vol 08 no 02

Sya'roni, Mazmur dkk. T.th. "Mushaf-mushaf Kuno di Indonesia”. Jakarta: Puslitbang Lektur Keagamaan Badan Litbang Agama dan Diklat Keagamaan Dapartemen Agama RI 